正会員 国 狭 覀輝臣 ${ }^{\dagger}$, 高 橋 誠一郎 ${ }^{\dagger}$, 正会員 伊 藤 修 朗 ${ }^{\dagger}$

\title{
A Study of DC Component Suppressing Method for Digital Signal Recording
}

Akiomi Kunisa $^{\dagger}$, Seiichiro Takahashi ${ }^{\dagger}$ and Nobuo Itoh $^{\dagger}$

あらまし ディジタルデータを記録する際, 変調方式の情報語に対する符号語の対応テーブルを 一定のデータブロック毎に変調後の直流成分が最小になるように適宜選択することにより，本来の 特性パラメー夕の值を維持したまま直流成分を抑圧できる方式を提案している.

\section{1. まえ がき}

近年，画像などの大量のデー夕を記録再生する光デ イスクにおいて, 半導体レーザ, ディスク媒体の改良 と共に, 信号処理による高密度化の研究が求められて いる. 高密度化の信号処理の重要な技術のひとつとし てディジタル記録変調方式がある. 従来からコンピュ ー夕の外部記憶装置である HDD (Hard Disk Drive) 用の記録変調方式としては, 高密度記録を行うために 最小反転間隔 $\left(T_{\min }\right)$ を大きくした $(1,7)$ RLL 符号 ${ }^{122}$ や $(2,7) \mathrm{RLL}$ 符号 ${ }^{3)}$ が開発, 実用化されてきた。

一方, 光ディスクのひとつである $\mathrm{CD}$ (Compact Disc)用の変調方式としては, $\operatorname{EFM}$ 符号 $((2,10)$ RLL 符号 $)^{4)}$ が開発されている。この方式は 8 ビット デー夕毎に直流成分を抑圧するビットを付加し，これ を制御することにより低周波成分を低減しているが, 最大反転間隔 $\left(T_{\max }\right)$ は従来の $(2,7) \mathrm{RLL}$ よりきく なっている.

また, $130 \mathrm{~mm}$ の $2 \mathrm{~GB}$ 光磁気ディスクでは $(1,7)$ RLL 符号を採用し, さらに, あるデータブロック毎 に直流成分制御用の付加ビットを挿入し，このビット の信号極性を累積電荷 DSV (Digital Sum Variation) が小さくなるように反転させて低周波成分の低減を行 っている ${ }^{5)}$ が, 直流成分制御ビットの間隔から決まる
周波数以下の低周波成分を抑圧できない欠点がある. そこで今回, 従来の $(2,7)$ RLL, $(1,7)$ RLLの $T_{\min }$ を減少させたり， $T_{\max }$ を増加させることなく, 直流付近の低周波成分を効率良く抑圧する新しい直流 成分抑圧方式を開発した。そして従来, 光磁気ディス クに用いられた方式と直流成分抑圧特性を計算機シミ ュレーションにより比較した結果, 本方式の方が優れ ていることを確認したので報告する。

\section{2. ディジタル記録変調方式に求められる要件}

一般に, ディジタル信号を高密度に記録するための ディジタル記録変調方式としては, 以下の条件を満足 する必要がある。

（1）最小反転間隔 $T_{\min }$ が大きい

$T_{\min }$ は光ディスク上の最小ピット長を決める值で あり, 記録密度, 信号帯域の点から大きいことが望ま しい.

（2）最大反転間隔 $T_{\max }$ が小さい

$T_{\max }$ は小さいほど再生信号から符号識別用のクロ ックを抽出することが容易になり，抽出したクロック のジッタ成分も小さくなる.

(3) 検出空幅 $T_{\mathrm{w}}$ が大きい

$T_{\mathrm{w}}$ は再生信号の時間軸変動に関する許容を示し, 大きいほど余裕が増大する。

キーワード：ディジタル変調方式, DC フリー, ディジタル記録, 記録信号処理

1994 年 8 月 4 日受付, 1995 年 9 月 6 日再受付

$\dagger$ 三洋電機株式会社 ハイパーメディア研究所(テ 503-01 岐皁県安八郡安八町大森 180, TEL 0584-64-4591)

$\dagger$ Hypermedia Research Center, Sanyo Electric Co., Ltd. (180, Ohmori, Anpachi-cho, Anpachi-gun, Gifu 503-01, Japan) 
（4）直流付近の低周波成分が少ない

記録する変調信号の直流付近の低周波成分が大きい と, 直流遮断によるDC ワンダリングが発生しアイパ ターンが劣化する. 再生方式によっては変調信号の低 周波成分がサーボ系へ妨害を及ぼすため, 直流付近の 低周波成分は少ない方がよい。

しかしながら，上記の条件はトレードオフの関係に あり，すべてを満足することは困難となる．たとえ ば，EFMのように直流成分を冗長ビットの付加によ り制御すると $T_{\text {max }}$ が大きくなり, 逆に従来の $(d, k)$ 制約 $(d<k)$ を守ろうとすると直流成分の抑圧度を大 きくできなかった，ただし， $d$ は変調信号内における 同一ビットの連続数の最小值, $k$ は最大值を示す.

そこで，これらを両立する新しい直流成分抑圧方法 について提案を行う.

\section{3. 新しい直流成分抑圧方式}

ここで提案する直流成分抑圧方式は，一般によく用 いられるブロック変換型ディジタル変調方式のすべて に適用することができるものである．以下に本方式の 動作原理, 実際の適用例およびその特性評価について 説明を行う。

\section{1 直流成分抑圧方式の原理}

ブロック変換型変調方式は図 1 の原理図に示すよう に $m$ ビットの情報語を， $(d, k)$ 制約を満足した $n$ ビ ット $(n \geqq m)$ の符号語に変換するするものである.こ のときの変調方式は, ある情報語に対して 1 個以上の 符号語からなる符号語群を用意し, 前後の接続条件に 従ってその中から 1 個の符号語を選択する. しかし， 変調は可逆符号を用いて行われるので, 基本的には情 報語に対して符号語群（符号語は 1 個以上であるが, 図では符号語が 1 個の場合を示す）は 1 対 1 に対応づ けられている。したがって，情報語に対する符号語群 の対応づけは図 2 に示すように 1 対 1 の写像関係があ れば任意でよいことから， $2^{m}$ 個の情報語に対する $2^{m}$ 個の符号語群の対応関係は $2^{m}$ ! 通り存在することに なる。
そこで, 今回提案する手法は, あるデータブロック 毎に $2^{m}$ ! 通りある情報語に対する符号語変換則（以 下, 変調テーブルと呼ぶ) の中から変調後に DSV が 0 に近くなるように順次変調テーブルを選択しながら, ディジタル変調をするものである。これにより, 従来 の変調方式の持つ $(d, k)$ 制約を満たしたままで, 直 流成分を効率良く抑圧することができる。

本方式の動作原理ブロック図を図 3 に示す．まず， 入力端子からのシリアルデータはレート変換器によっ て $m$ ビット単位の情報語に変換される. 次に, $m$ ビ ットの情報語に対して $2^{m} ! （=j ）$ 通りある符号語テ ーブルについて, それぞれ一定のデータブロックを変 調した時のブロック内での | DSV | の最大值を変調 コードの累積電荷を示すCDS (Codeword Digital Sum）を用いて計算する。得られた $|\mathrm{DSV}|$ のうち, その值が最も小さいテーブルをそのデータブロックの 変調テーブルとして選択して変調するとともに, その

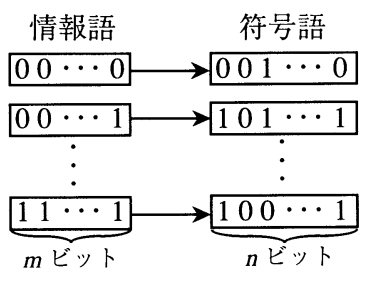

図 1 ブロック変換型変調方式 Method of a block modulation.

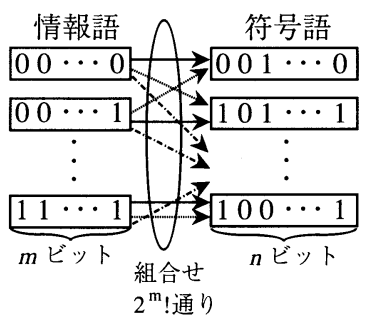

図 2 情報語と符号語の対応関係 Combination of source data with channel data.

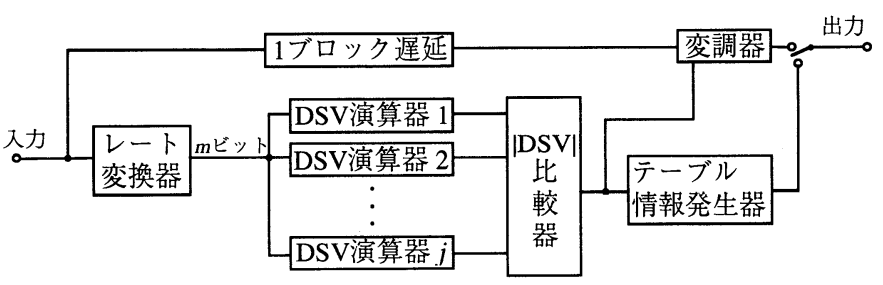

図 3 動作原理ブロック図

Block diagram for the signal processing of data coding. 
テーブル情報を付加して記録するものである．

以上のように, 本手法は一定のデータブロック毎に 変調テーブルをDSV に基づいて変化させることで直 流付近の低周波成分を抑圧する手法であり，従来から 開発されているテーブルが存在するすべてのブロック 変換型変調方式に適用可能である.

\section{$3.2(1 ， 7)$ RLL 符号への適用}

本方式を実際にブロック変調方式のひとつである Jacoby らにより提案されている 2-3 変調方式 ${ }^{1)}$ に適 用してみる。

図 4 はその変調規則を示す．左の表が 2 ビットから 3 ビットへの変換規則を, 右の表が符号語接続の際に 境界で 1 が連続する場合のビット変換規則を示してい る。

図 4 では変調テーブルの組合せは $(\mathrm{A}, \mathrm{a}), \quad(\mathrm{B}$, b), (C, c), (D, d) となっているが, これが, (A, a), $(\mathrm{B}, \mathrm{b}),(\mathrm{C}, \mathrm{d}),(\mathrm{D}, \mathrm{c})$ となっても変調可能 である。このような組合せは $2^{2} !=24$ 通り存在す る。この各々の組合せに対して, 1 データブロック内 に発生した最大の $|\mathrm{DSV}|$ をそれぞれ求め, その中 から最小の｜DSV｜を算出する組合せを示すテーブ ルに基づいて変調を行う.

\section{3 本方式の特性評価}

本方式の直流成分抑圧特性を評価するため, ある一 定データブロック毎に挿入された直流成分制御ビット をDSV の值が小さくなるように制御する従来方式と の比較シミュレーションを行った。シミュレーション に用いた情報信号としては $\mathrm{M}$ 系列信号 $\left(x^{32}+x^{22}+x^{2}\right.$ $+x+1)$ を用いた。また，フレーム構成は図 5 に示す ように, データブロックの先頭に SYNC データ, そ の後ろに本方式の場合は変調テーブル情報信号を, 従 来方式の場合は直流成分制御ビットをそれぞれ付加し ている。このようなフレーム構成の情報信号をそれぞ れの方式で直流成分を制御しながら 2-3 変調した信号 波形を特性評価した。以降, 評価結果図中の $\mathrm{A}$ は従 来方式を, $\mathrm{B}$ は本方式を示し, アルファベットに続く 数字は評価に用いた $\mathrm{M}$ 系列データのビット数を表す ものとする.

図 6 は,データブロック長を 800 ビットとした場合 の従来方式（図中の A 800）と本方式（B 800）により それぞれ求められた変調信号の周波数スペクトラムを 示している．ただし， $f_{c}$ はチャンネルビットの周波 数を示す.この図から, 従来方式が規格化周波数 0.0002 付近からスペクトラムが減衰し始めているの に対し, 本方式が 0.002 付近から減衰していることが わかる。

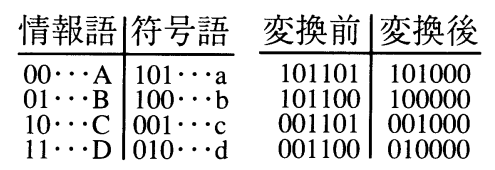

図 $4(1,7)$ RLL 変調符号

Example of $(1,7)$ RLL modulation code.

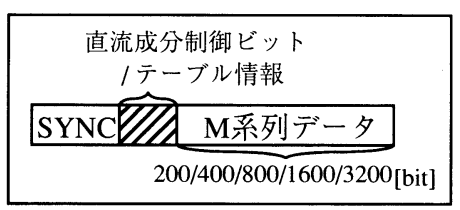

図 5 フレーム構成

Structure of a frame.

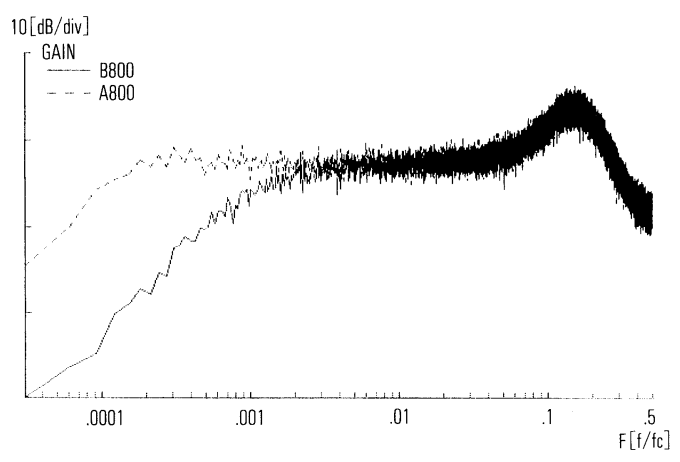

図 6 ２-3 変調信号の周波数特性

Frequency charateristics of channel data.

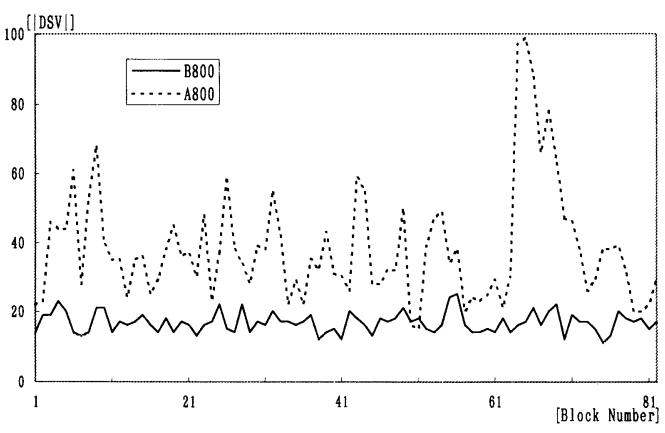

図 7 データブロック内最大 $|\mathrm{DSV}|$ の推移 Change of maximum $|\mathrm{DSV}|$ in each block.

図 7 は, 約 80 データブロックの連続データに対し て, 1 データブロック内で計算された最大の | DSV | の推移を示している.フレームに 1 回の直流成分制御 ビットの反転/非反転による制御を行った従来方式で は，50ブロック目のように $|\mathrm{DSV}|$ を小さくできる 場合と 65 ブロック目のように $|\mathrm{DSV}|$ を小さくでき ない場合があり, $|\mathrm{DSV}|$ の変動が激しい。一方, 


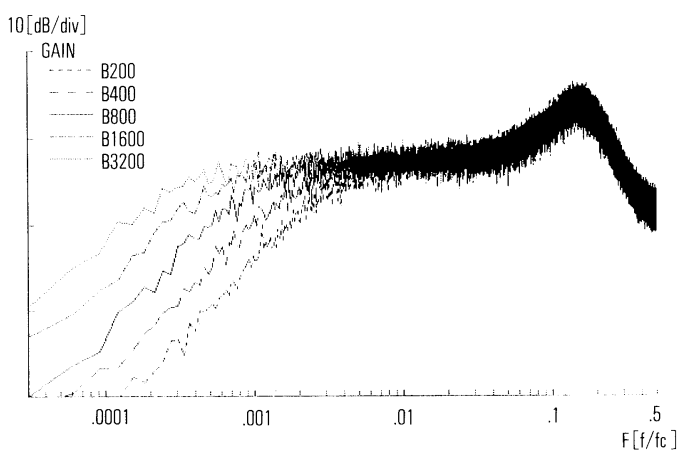

図 8 異なるデータブロック長での周波数特性の比較 Frequency characteristics of channel data in coding with 5 kinds of block length.

本方式は, 情報語の変化に適応して $|\mathrm{DSV}|$ が 0 に 近くなるように変調テーブルをデータブロック毎に切 り替えている結果，| DSV | が 15 程度と小さく, 安 定している。

図 8 は, 本方式のデータブロック長を 200 ビット, 400 ビット， 800 ビット， 1600 ビット， 3200 ビットと 変化させた場合の周波数スペクトラムを比較した図で ある。この図から，データブロック長が長くなるにし たがって低周波成分の抑圧効果が少なくなっているこ とがわかる。したがって，本方式を用いる場合，どの 程度の低周波成分の抑圧が必要であるかによりデー夕 ブロック長を適切に決定する必要がある.

\section{4. む す び}

種々のブロック変換型変調方式に適用可能である直 流成分抑圧方式を提案した。また，周波数解析を行う ことで，本方式の有効性を確認した。

しかし，本手法は，テーブル情報を示すビット列に エラーが発生した場合，そのデータブロックの復調が
行えなくなるという欠点がある．したがって，誤り訂 正符号を付加するなどして，エラー発生に対処する必 要がある．今後は，このような点も考慮しながら，そ の他の変調方式にも本手法を適用していく予定であ る.

\section{〔参 考 文 献〕}

1) G. V. Jacoby, P. Hodges: "Binary Two-Thirds Rate Code with Full Word Look-Ahead", IEEE Trans. Mag., 20, 5, pp. 709-714 (1984)

2) T. Horiguchi, K. Morita : "An Optimization of Modulation Codes in Digital Recording", IEEE Trans. Mag., 12, 6, pp. 740-742 (Nov. 1976)

3) J. Eggenberger, P. Hodges: "Sequential Encoding and Decoding of Variable Word Length, Fixed Rate Data Codes”, U. S. Patent, 4115768 (Sep. 19, 1978)

4) K. A. Immink, U. Gross: "Optimization of Low-Frequency Properties of Eight-to-Fourteen Modulation", Radio Electron. Eng., 53, 2, pp. 63-66 (Feb. 1983)

5) Standard ECMA-195, Data Interchange on $130 \mathrm{~mm}$ Optical Disk Cartridges-Capacity : 2 Gigabyte Per Cartridge(Dec. 1993)

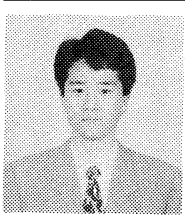

国狭垔輝臣平成 4 年, 広島大学工学部第 二類卒業. 平成 6 年, 同大学院工学研究科博 土課程前期システム工学専攻修了. 同年, 三 洋電機 (株) 入社. ディジタル信号処理, 知的 信号処理に関する研究に従事. 現在，同社八 イパーメディア研究所に勤務. 正会員.

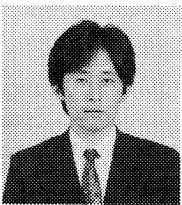

高橋誠一郎 平成 2 年, 愛媛大学大学院工 学研究科修士課程修了. 同年, 三洋電機 (株) に入社. ハイビョン機器の研究開発を経て, ディジタル信号処理の研究に従事. 現在, 同 社, ハイパーメディア研究所に勤務。

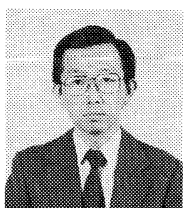

伊脽漛 修朗 昭和 57 年, 福井大学大学院 修士課程修了. 同年, 三洋電機(株)に入社. 平成 7 年, 岐阜大学大学院博士課程修了. テ イジ夕ル画像処理および波形等化に関する研 究開発に従事. 現在, 三洋電機(株)ハイパー メディア研究所に勤務. 工学博士. 正会員. 